\title{
'One-pot' sequential enzymatic modification of synthetic glycolipids in vesicle membranes
}

DOI:

10.1039/C7CC09148F

\section{Document Version}

Accepted author manuscript

Link to publication record in Manchester Research Explorer

\section{Citation for published version (APA):}

Craven, F., Silva, J., Segarra-Maset, MD., Huang, K., Both, P., Gough, J., Flitsch, S., \& Webb, S. (2018). 'One-pot' sequential enzymatic modification of synthetic glycolipids in vesicle membranes. Chemical Communications, 54(11), 1347-1350. https://doi.org/10.1039/C7CC09148F

\section{Published in:}

Chemical Communications

\section{Citing this paper}

Please note that where the full-text provided on Manchester Research Explorer is the Author Accepted Manuscript or Proof version this may differ from the final Published version. If citing, it is advised that you check and use the publisher's definitive version.

\section{General rights}

Copyright and moral rights for the publications made accessible in the Research Explorer are retained by the authors and/or other copyright owners and it is a condition of accessing publications that users recognise and abide by the legal requirements associated with these rights.

\section{Takedown policy}

If you believe that this document breaches copyright please refer to the University of Manchester's Takedown Procedures [http://man.ac.uk/04Y6Bo] or contact uml.scholarlycommunications@manchester.ac.uk providing relevant details, so we can investigate your claim.

\section{OPEN ACCESS}




\section{Accepted Manuscript}

This article can be cited before page numbers have been issued, to do this please use: F. Craven, J. Silva, M. Segarra-Maset, K. Huang, P. Both, J. Gough, S. L. Flitsch and S. Webb, Chem. Commun., 2018, DOI:
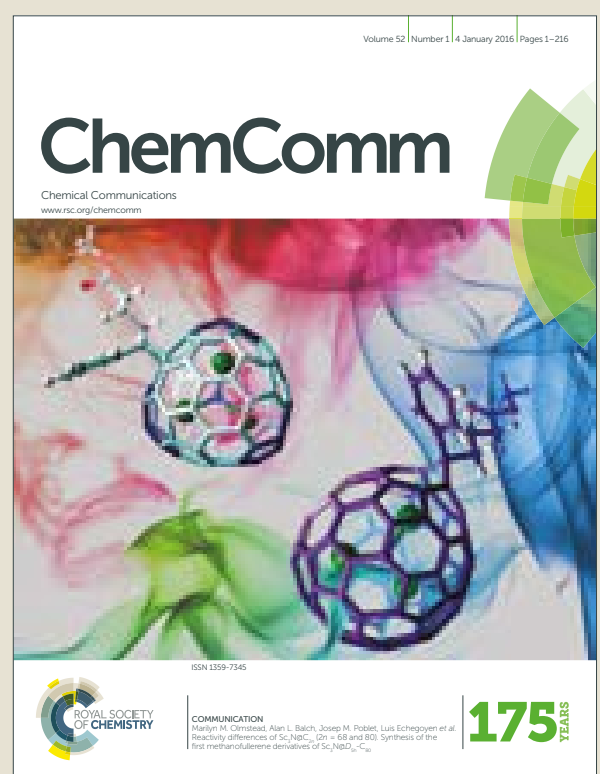

This is an Accepted Manuscript, which has been through the Royal Society of Chemistry peer review process and has been accepted for publication.

Accepted Manuscripts are published online shortly after acceptance, before technical editing, formatting and proof reading. Using this free service, authors can make their results available to the community, in citable form, before we publish the edited article. We will replace this Accepted Manuscript with the edited and formatted Advance Article as soon as it is available.

You can find more information about Accepted Manuscripts in the author guidelines.

Please note that technical editing may introduce minor changes to the text and/or graphics, which may alter content. The journal's standard Terms \& Conditions and the ethical guidelines, outlined in our author and reviewer resource centre, still apply. In no event shall the Royal Society of Chemistry be held responsible for any errors or omissions in this Accepted Manuscript or any consequences arising from the use of any information it contains. 


\section{Journal Name}

\section{COMMUNICATION}

\section{'One-pot' sequential enzymatic modification of synthetic glycolipids in vesicle membranes}

Received 00th January 20xx, Accepted 00th January 20xx

DOI: $10.1039 / x 0 x x 00000 x$
Faye L. Craven, ${ }^{a, b}$ Joana Silva, ${ }^{a, b, c}$ Maria D. Segarra-Maset, ${ }^{a, b}$ Kun Huang, ${ }^{a, b}$ Peter Both, ${ }^{a, b}$ Julie E. Gough, ${ }^{\mathrm{c}}$ Sabine L. Flitsch ${ }^{\mathrm{a}, \mathrm{b}, *}$ and Simon J. Webb ${ }^{\mathrm{a}, \mathrm{b}, *}$

www.rsc.org/

$\beta(1,4)$-Galactosyltransferase ( $\beta 4 \mathrm{Gal}-\mathrm{T} 1$ ) and $T$. cruzi trans-sialidase (TcTS) have been used in a 'one-pot' cascade to provide vesicles (liposomes) with a trisaccharide coating. These soluble enzymes catalysed the transfer of galactose then sialic acid onto a synthetic $\mathrm{N}$-acetylglucolipid embedded in the bilayers. Clustering of this substrate into microdomains increased the rate of sialylated lipid production, showing that an increase in $\beta 4 \mathrm{Gal}-\mathrm{T} 1$ activity is carried through the enzymatic cascade. These coatings modulated cell recognition. Hepatocellular carcinoma cells took up vesicles modified by $\beta 4 \mathrm{Gal}-\mathrm{T} 1$ alone more extensively than sialylated vesicles produced by 'one-pot' sequential enzymatic modification.

Oligosaccharides in the glycan layer on the cell surface play central roles in cell migration, tissue patterning, immune responses and cell death. ${ }^{1} \mathrm{~A}$ common saccharide on the terminus of N-glycans is sialic acid (Neu5Ac, Nacetylneuraminic acid), found for example in the sequence Neu5Ac( $\alpha 2-6)$ Gal $(\beta 1-4) G l c N A c{ }^{1 b}$ Sialic acid also found in ganglioside lipids, e.g. Neu5Ac( $\alpha 2-3)$ Gal $\beta 1-4) G l c$ in the $G_{3}$ glycolipid headgroup. ${ }^{2}$ Gangliosides have important roles in cellular recognition and cell-to-cell communication, and are often clustered together in lipid rafts on the cell surface. ${ }^{2}$

The recognition of cell-surface sialic acid groups can be mediated through sialic acid-binding immunoglobulin-type lectins (siglecs), a family of cell-surface lectins that facilitate cellular recognition by immune cells. ${ }^{3}$ As they exhibit restricted expression to a few cell types and can be overexpressed in diseased cells, they can be attractive targets for biomedical applications. ${ }^{4,5}$ For example, oligosaccharide-coated liposomes and nanoparticles have been developed that target sialoadhesin (Sn, Siglec-1, or CD169), an endocytic surface

\footnotetext{
a. School of Chemistry, University of Manchester, Oxford Road, Manchester M13 GPL, United Kingdom.

${ }^{b}$. Manchester Institute of Biotechnology, University of Manchester, 131 Princess St, Manchester M1 7DN, United Kingdom. E-mail: sabine.flitsch@manchester.ac.uk; S.Webb@manchester.ac.uk; Fax: +44(0)-161-306-5201; Tel: +44(0)-161-306-4524 c. School of Materials, University of Manchester, MSS Tower, Manchester, M13 9PL, United Kingdom.

Electronic Supplementary Information (ESI) available: Vesicle formation, enzymatic transformation and cell culture procedures. RP-HPLC procedures and analysis. 1 DPPC vesicle data. CFM and flow cytometry details. See DOI: 10.1039/x0xx00000x
}

receptor that preferably binds glycans terminating with a Neu5Ac( $\alpha 2-3)$ Gal $(\beta 1-4)$ GIcNAc sequence. ${ }^{6}$

The synthesis of oligosaccharide motifs can be demanding, ${ }^{7}$ but chemoenzymatic methods ${ }^{8}$ can provide selective and efficient routes to glycolipids. ${ }^{9}$ The soluble enzymes that are typically used can also be applied in situ to modify bilayerembedded glycolipids; TcTS catalysed the sialylation of synthetic lactolipids embedded in phospholipid vesicles to produce a synthetic sialylated "glycocalyx". ${ }^{10}$ Similarly, bovine B4Gal-T1 could produce vesicles with a synthetic LacNAc "glycocalyx". ${ }^{11}$ Using synthetic glycolipids allows the incorporation of design features that can provide mechanistic insights; the perfluoroalkyl-pyrene membrane anchor on these synthetic lipids ${ }^{10,11}$ permitted the effect of changing substrate distribution across the bilayer to be studied. These glycolipids disperse across the surface of liquid disordered $\left(I_{d}\right)$ bilayers but phase separate into lipid microdomains (simple models of lipid rafts) in liquid ordered membranes $\left(\mathrm{I}_{0}\right) ;^{12}$ this substrate clustering caused an increase in the rate of $\beta 4 \mathrm{Gal}-\mathrm{T} 1$ catalysis whereas TcTS catalysis was not significantly altered.

To find faster routes to phospholipid vesicles with more complex "glycocalyces", we hoped to exploit the high selectivity of enzyme catalysis. It was envisaged that $\beta 4 \mathrm{Gal}-\mathrm{T} 1$ and TcTS could operate consecutively in situ to build a Neu5Ac( $\alpha 2-3)$ Gal( $\beta 1-4)$ GlcNAc trisaccharide on a vesicle surface, via a simple 'one-pot' reaction (Figure 1a). If a cascade of enzymatic glycosylations, as recently exemplified on gold surface-bound substrates, ${ }^{13}$ were shown to operate at vesicle surfaces, a pathway may be opened to low cost and high throughput manufacturing of cell-targeting liposomes. More specifically, sialic acid terminated lipids in liposomal formulations are reported to improve circulation half-lives within the bloodstream. ${ }^{14}$ Insights into the role(s) of the bilayer during catalysis may also be obtained by monitoring the rate of formation of intermediate $\mathbf{2}$ and sialic acid product 3. Comparison with analogous reactions in solution can show how the lipid anchor and the bilayer affects the rate of each enzymatic step, and changing the bilayer phase can show how substrate clustering into microdomains affects each enzyme. 


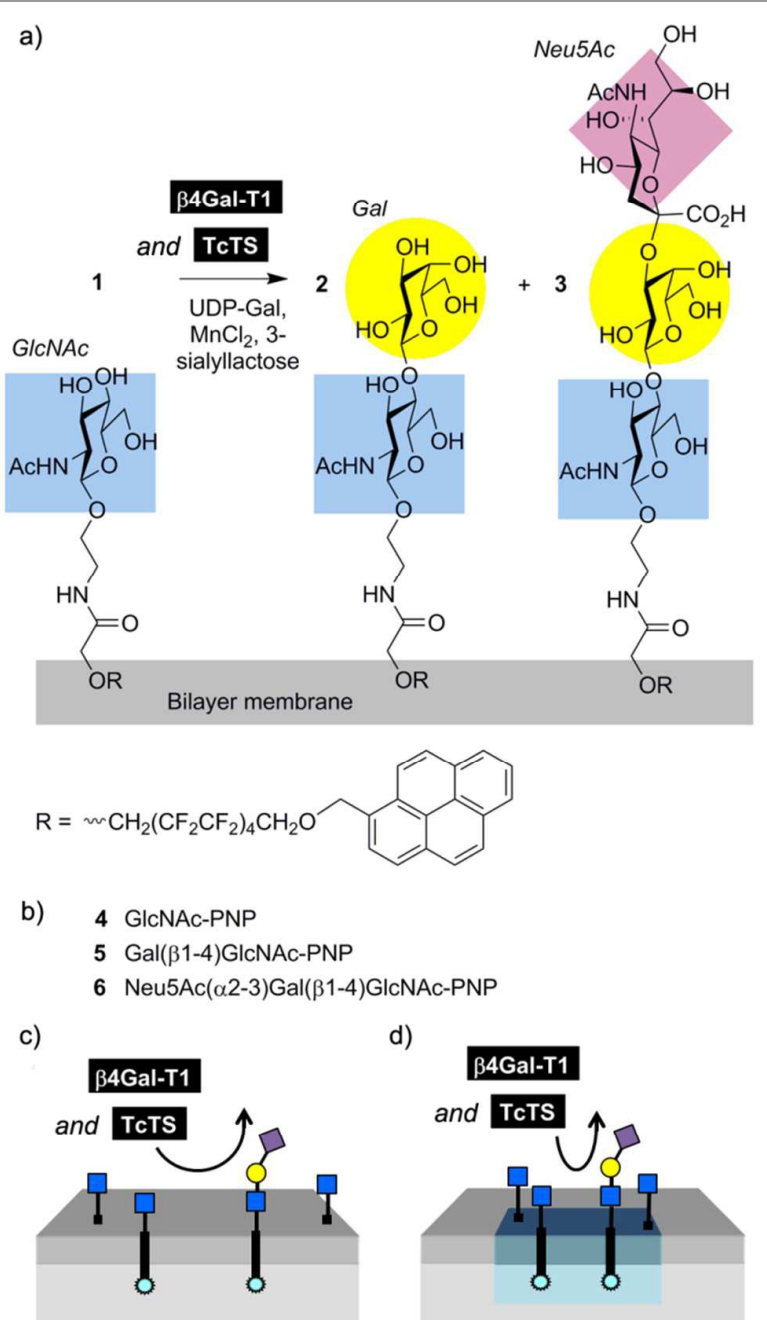

Figure 1: (a) 'One-pot' enzymatic transformation of membrane-bound synthetic glycolipid 1 by $\beta 4 \mathrm{Gal}$-T1 and TcTS to give $\mathbf{2}$ and 3. (b) Substrate $p$-nitrophenyl (PNP) GICNAc 4, for solution phase control studies, and products $\mathbf{5}$ and $\mathbf{6}$. (c) GICNAc lipid $\mathbf{1}$ is dispersed across the surface of liquid disordered $\left(I_{d}\right)$ bilayers (e.g. dimyristoy phosphatidylcholine, DMPC) but (d) phase separates to form lipid microdomains (pale blue regions) in liquid ordered membranes (Io, e.g. DMPC-cholesterol). ${ }^{11}$

Initially, conditions suitable for both enzymes had to be developed in solution using GIcNAc-PNP 4 (Figure 1b), as the separate reactions were conducted under different conditions. ${ }^{10,11}$ The reaction temperature was lowered from 37 ${ }^{\circ} \mathrm{C}$ to $22^{\circ} \mathrm{C}$, to make the methodology more applicable to drugloaded liposomes; bilayer leakiness can increase significantly with temperature. ${ }^{15} 3$-Sialyllactose had to be used in the place of fetuin, as fetuin catalysed the hydrolysis of $\mathbf{4}$ (see the ESI). Reactions were monitored by reversed phase analytical HPLC at $300 \mathrm{~nm}$, with conversion data calculated from peak areas.

HPLC analysis of the reaction mixture from the transformation of $\mathbf{4}$ showed the sialylated final product 6 formed rapidly and its concentration peaked at 40 minutes (Figure $2 b$ ), after which it remained the major product (>60\% of all PNP fractions). The PNP-GIcNAc intermediate $\mathbf{5}$ was also formed rapidly, but reached its maximum proportion of $30 \%$ within 10 minutes and subsequently slowly decreased. The starting saccharide $\mathbf{4}$ was rapidly and almost completely consumed ( $<10 \%$ of final mixture after 20 minutes).
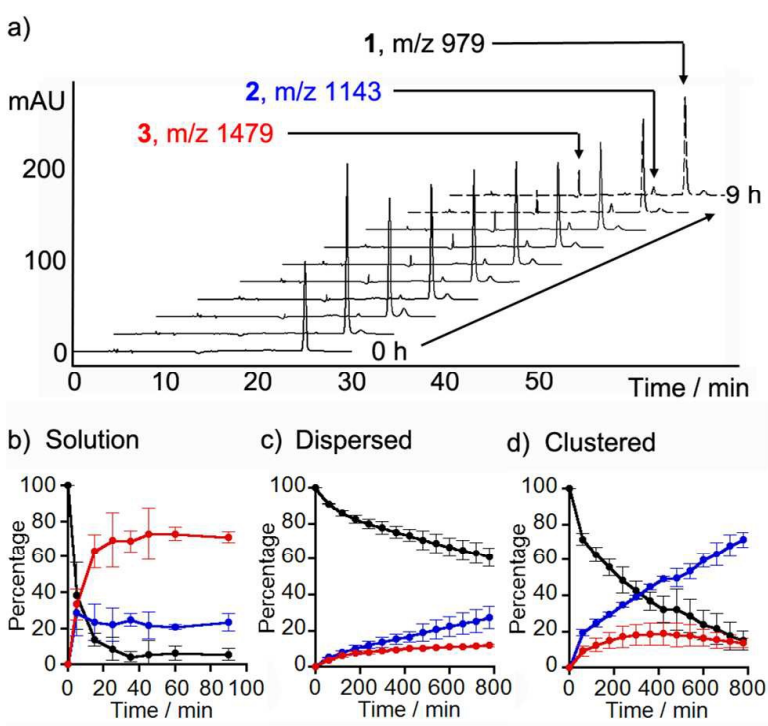

Figure 2: (a) HPLC traces showing product formation during enzymatic glycosylation of $8.5 \% \mathrm{~mol} / \mathrm{mol} 1$ in DMPC vesicles by $\beta 4$ Gal-T1 and TcTS. HPLC DAD absorbance monitored at $346 \mathrm{~nm}, \mathrm{~m} / \mathrm{z}$ values from LCMS indicated for each peak. (b-d) Plots showing the change over time in the relative proportions of GlcNAc (black, $\bullet$ ), LacNAc $($ blue, $\bullet$ ) and Neu5Ac (red, $\bullet$ ) terminated products upon 'one-pot' transformation by B4Gal-T1 and TcTS of (b) 4 in solution; (c) 1 dispersed over the surface of DMPC vesicles; (d) 1 clustered into microdomains in the membranes of DMPC/cholesterol vesicles. Error bars show standard deviations from three measurements.

The HPLC methodology was then adjusted to be compatible with vesicle mixtures. Lipid $\mathbf{1}$ was mixed with matrix lipids (9:1 mol ratio) and extruded into $800 \mathrm{~nm}$ diameter large unilamellar vesicles (LUVS) following established protocols. ${ }^{11}$ The matrix lipids used for the vesicles were either dimyristoyl phosphatidylcholine (DMPC, $I_{d}$ phase at room temperature; lipid $\mathbf{1}$ is dispersed) or a 1:1 DMPC:cholesterol mixture ( $I_{0}$ phase; lipid $\mathbf{1}$ clustered into microdomains). ${ }^{11}$ The fraction of $\mathbf{1}$ in each bilayer was determined by UV-visible spectroscopy to be $8.5 \% \mathrm{~mol} / \mathrm{mol}$ in DMPC and $6.4 \% \mathrm{~mol} / \mathrm{mol}$ in DMPC-chol. ${ }^{11}$ Each vesicle suspension was treated with UDP-Gal, $\mathrm{MnCl}_{2}, \beta 4 \mathrm{Gal}-\mathrm{T} 1,3-$ sialyllactose and TcTS at room temperature $\left(22^{\circ} \mathrm{C}\right.$, see ESI). ${ }^{16}$

Reversed phase HPLC analysis of $8.5 \% \mathrm{~mol} / \mathrm{mol} 1$ in DMPC vesicles showed three main bands, which were assigned to glycolipids 1, 2 and 3 (Figure 2a). Each of these peaks showed characteristic pyrene absorbance with $\lambda_{\max }=346 \mathrm{~nm}$. LCMS confirmed the identity of the peaks (see the ESI); the peak with a retention time of 23 minutes was starting material $(\mathrm{m} / \mathrm{z}$ of 979.3, $\left.[\mathrm{M}]^{+}\right)$, intermediate 2 eluted at 21 minutes, $(\mathrm{m} / \mathrm{z}$ of $\left.1142.8,[\mathrm{M}]^{+}\right)$and sialylated product 3 appeared at 13 minutes $\left(\mathrm{m} / \mathrm{z}\right.$ of $\left.1479.0,[\mathrm{M}+2 \mathrm{Na}]^{+}\right)$. As expected, retention time on the hydrophobic column decreased after each sugar addition.

Comparison of the initial rates showed galactosylation by B4Gal-T1 of 1 in either bilayer type was much slower than the corresponding transformation of $\mathbf{4}$ in solution, but in bilayers the proportion of galactosylated intermediate $\mathbf{2}$ continued to 
increase, even reaching $70 \%$ (Figure $2 \mathrm{~d}$ ). The accumulation of galactosylated intermediate $\mathbf{2}$ in both 1-DMPC vesicles and $\mathbf{1}$ $\mathrm{DMPC} / \mathrm{chol}$ vesicles contrasts with the analogous process in solution, where the fraction of galactosylated intermediate $\mathbf{5}$ quickly peaks ( $30 \%$ at 10 mins) then slowly decreases. These observations suggest poorer rate matching between the first and second catalytic steps for the transformation of $\mathbf{1}$ in bilayers, which leads to accumulation of the intermediate instead of a low steady state concentration. Indeed the fraction of sialylated product $\mathbf{3}$ in both bilayer types stayed below $20 \%$, unlike 6 in solution which reached $\sim 70 \%$ after just $1.6 \mathrm{~h}$. To improve the extent of sialylation, sialyltransferases that make the same glycosidic bond as TcTS, such as ST3Gal4 and PmST1, ${ }^{8 c, e}$ could be useful substitutes. The difference between the rates for transforming $\mathbf{4}$ and membrane-bound $\mathbf{1}$ suggest that the lipid anchor on the GIcNAc headgroup (which leads to self-assembly in solution) ${ }^{17}$ and steric hindrance at the membrane surface significantly impairs catalysis by these soluble enzymes. Furthermore, this inhibition is stronger for TcTS than $\beta 4 \mathrm{Gal}-\mathrm{T} 1$.

Comparing the "one-pot" transformation of 1-DMPC with that of 1-DMPC/chol revealed the effect of the membrane. Under "one-pot" conditions, a $~ 3$-fold increase in initial rate (from $9 \mu \mathrm{Mh}^{-1}$ to $25 \mu \mathrm{Mh}^{-1}$ ) for the production of 2 by $\beta 4 \mathrm{Gal}-\mathrm{T} 1$ was observed when lipid $\mathbf{1}$ was clustered in microdomains (1$\mathrm{DMPC} / \mathrm{chol}$ ) compared to when $\mathbf{1}$ was dispersed (1-DMPC). This is similar to, albeit lower than, the 9-fold enhancement observed for $\beta 4 G$ Gal-T1 acting alone and under different conditions. ${ }^{11}$ These "one-pot" conditions also led to a 2 -fold higher initial rate (from $6 \mu \mathrm{Mh}^{-1}$ to $12 \mu \mathrm{Mh}^{-1}$ ) for the TcTScatalysed production of $\mathbf{3}$ when the lipids were clustered, despite TCTS being insensitive to the lateral distribution of substrate (dispersed or clustered) across the membrane. ${ }^{10} \mathrm{We}$ suggest that faster production of $\mathbf{3}$ arises indirectly from faster B4Gal-T1 catalysed transformation of clustered 1, which produces higher concentrations of the intermediate $\mathbf{2}$.

Recognition by cells is a key test that would confirm successful enzymatic modification of the synthetic "glycocalyx" on these vesicles. Demonstrating cellular recognition also has wider significance, as in situ enzyme-catalysed labelling of drug-loaded liposomes with oligosaccharides may provide a new route to selective cell targeting. Potentially the ability to turn on glycolipid clustering may enhance liposome uptake, through strengthening of multivalent recognition at the cell surface (the cluster glycoside effect). ${ }^{18}$ Hepatocellular carcinoma (HepG2) cells were identified as a suitable cell line for the assay, as this human epithelial cell line from hepatocytic carcinoma is known to express asialoglycoprotein receptor (ASGPR) on its surface. ${ }^{19}$ ASGPR recognises terminal galactose residues, so should demonstrate how recognition can be tuned by choosing the right combination of enzymes.

For proof-of-concept studies, 1-DMPC LUVs were selected. "One-pot" transformation of these vesicles produced a higher sialylated/galactosylated lipid ratio ( $c a .1$ after $3 \mathrm{~h}$ ) compared to 1-DMPC/chol vesicles (ca. 0.5 after $3 \mathrm{~h}$ ), which should maximise any differences when compared to vesicles transformed by $\beta 4 \mathrm{Gal}-\mathrm{T} 1$ alone. A fluorescent lipid,
rhodamine-DHPE, was added to the bilayers $(0.1 \% \mathrm{~mol} / \mathrm{mol})$ to permit vesicle tracking by confocal fluorescence microscopy (CFM) and flow cytometry. The cell culture conditions were optimised (see ESI), and the cells stained with DNA dye DAPI and Alexa Fluor 488-conjugated phalloidin to label F-actin.

a)

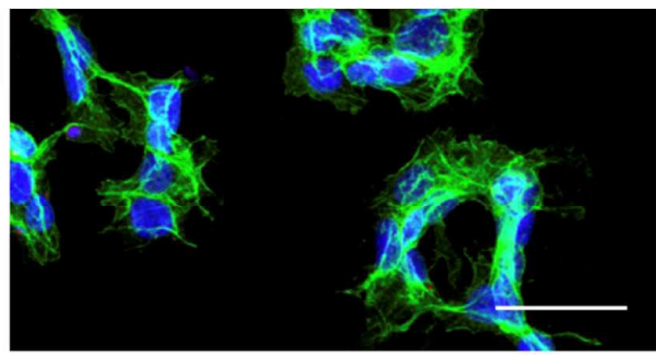

b)

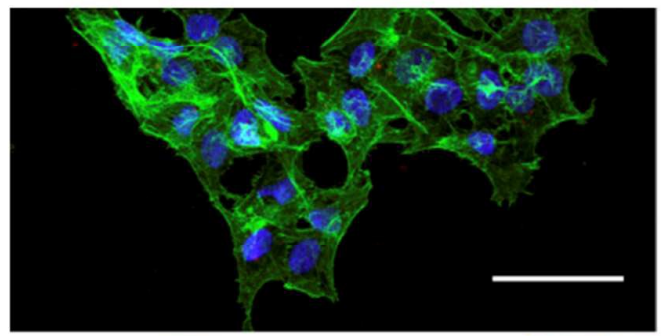

c)

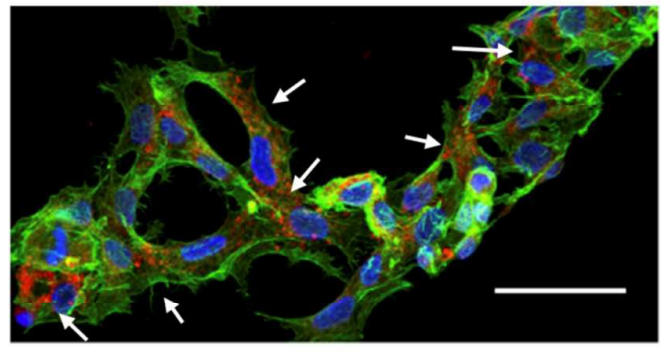

d)

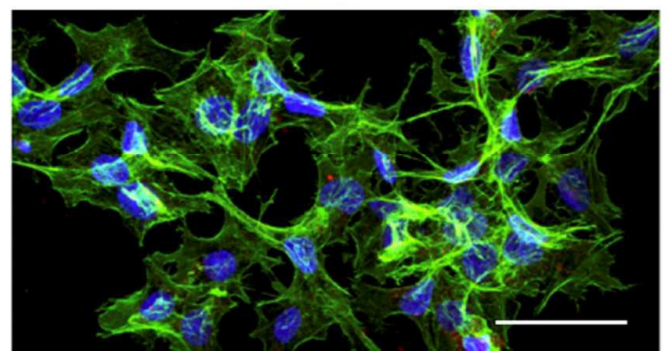

Figure 3: (a-d) Confocal microscopy images of enzymatically transformed 1-DMPC vesicles ( $5.3 \mu \mathrm{g} / \mathrm{mL}$ of lipid, rhodamine-DHPE labelled, red fluorescence) incubated with HepG2 cells (after $24 \mathrm{~h}$ of cell adhesion, $2.7 \times 10^{4}$ cells $/ \mathrm{mL}$ ) for $3 \mathrm{~h}$. a) DMPC only; b) 1 DMPC (GICNAc coating); c) 1-DMPC+ $\beta 4$ Gal-T1 mixture (LacNAc coating); d) 1 DMPC+ $\beta 4$ Gal-T1+TcTS mixture (some sialic acid coating). Cells stained with DAPI (blue fluorescence, DNA) and Alexa Fluor 488-conjugated phalloidin (green fluorescence, Factin). Samples imaged using an oil $63 \times$ objective. Scale bars $=50 \mu \mathrm{m}$. Cellular structures containing vesicles indicated with arrows.

After incubation ( $3 \mathrm{~h}$ ) of HepG2 cells with uncoated and saccharide-coated vesicles, CFM images (Figure 3) appear to show the best uptake of 1-DMPC vesicles that had been transformed by $\beta 4 G a l-T 1$ (Figure $3 c$ ). The images suggest endocytosis of these galactosylated vesicles by the cells, as many red fluorescent structures are around the f-actin (green fluorescence) within the cell and a considerable proportion 
surround the cell nucleus (blue fluorescence). In contrast, vesicles that are uncoated or doped with 1 alone (GIcNAc surface) were not well taken up. Interestingly, sequential modification with $\beta 4 \mathrm{Gal}-\mathrm{T} 1$ and TcTS significantly decreased vesicle uptake (consistent with literature reports ${ }^{14}$ ), despite the relatively low level of sialylation (ca. $10 \%$ of all glycolipid).

Flow cytometry was used to quantify vesicle internalisation at $3 \mathrm{~h}$, as well as at $24 \mathrm{~h}$. Cell culture plates were cultured in parallel under the same conditions used for the samples imaged by CFM. Increasing the cell/vesicle incubation time from $3 \mathrm{~h}$ to $24 \mathrm{~h}$ increased uptake by cells for vesicles of all types (see ESI). However within each incubation time, there was always significantly lower uptake of DMPC vesicles compared to saccharide-coated vesicles. Comparison of coating types at $3 \mathrm{~h}$ showed that 1-DMPC (GlcNAc-coated) and 1-DMPC+ $\beta 4$ Gal-T1+TcTS (some sialic acid coating) had similar means for the rhodamine fluorescence per cell. However the mean for the 1-DMPC+ $\beta 4$ Gal-T1 mixture (LacNAc coating) was significantly higher, which indicated greater vesicle internalisation and correlated with the CFM images. This difference was largely due to a significant population of cells that had internalised large numbers of fluorescent vesicles; the median values for all types of saccharide-coated vesicles were not significantly different. However the differences between all types of saccharide-coated vesicles disappeared after longer incubation times ( $24 \mathrm{~h}$ ), and at higher vesicle concentrations (5 $x$, see ESI). Overall these studies show saccharide coatings improve vesicle recognition by cells, but selectivity between coatings shows both time and concentration dependence.

These studies have demonstrated that simple sequential enzymatic glycotransformations can be conducted on a bilayer interface in a 'one-pot' system. Quantifying reaction progress by HPLC and LCMS showed that reaction rates are much slower than for the transformation of analogous substrates in solution, which was ascribed to the effect of the lipid anchor and the bilayer, and that not all enzymes are inhibited to the same extent. The bilayer plays another important role; a 3fold enhancement in initial rate for the production of lipid 2 was found when substrate lipid $\mathbf{1}$ was clustered in microdomains. This rate increase was continued over to the TcTS-catalysed production of lipid $\mathbf{3}$, demonstrating that production of the final lipid is affected by distribution across the membrane, even if not all the enzymes used in the cascade are sensitive to the distance between substrates.

Cascades of chemoenzymatic transformations at phospholipid bilayer interfaces may provide lower cost and higher throughput routes to cell-targeting liposomes, using routes from common liposomal intermediates. Such chemoenzymatic methods should have particular impact for liposomal formulations that include cell-targeting oligosaccharides, as the cost of chemically synthesising lipooligosaccharides can be prohibitive.

\section{Conflicts of interest}

There are no conflicts to declare

\section{Acknowledgements}

We thank the BBSRC (DTP PhD studentships to FLC and JS) and the EPSRC (EP/N009134/1) for funding.

\section{Notes and references}

1 (a) M. E. Griffin and L. C. Hsieh-Wilson, Cell Chem. Biol. 2016, 23, 108-121. (b) A. Varki, R. D. Cummings, J. D. Esko, H. H. Freeze, P. Stanley, C. R. Bertozzi, G. W. Hart and M. E. Etzler editors. Essentials of Glycobiology. 2nd ed. Cold Spring Harbor Laboratory Press, Cold Spring Harbor (NY), 2009.

2 C.-L. Schengrund, Trends Biochem. Sci. 2015, 40, 397-406.

3 M. S. Macauley, P. R. Crocker and J. C. Paulson, Nat. Rev. Immunol. 2014, 14, 653-666.

4 J. Müller and L. Nitschke, Nat. Rev. Rheumatol. 2014, 10, 422-428.

5 W. C. Chen, G. C. Completo, D. S. Sigal, P. R. Crocker, A. Saven and J. C. Paulson, Blood, 2010, 115, 4778-4786.

6 (a) N. Kawasaki, J. L. Vela, C. M. Nycholat, C. Rademacher, A. Khurana, N. van Rooijen, P. R. Crocker, M. Kronenberg and J. C. Paulson, Proc. Natl. Acad. Sci. U.S.A. 2013, 110, 78267831. (b) C. M. Nycholat, C. Rademacher, N. Kawasaki and J. C. Paulson, J. Am. Chem. Soc. 2012, 134, 15696-15699.

7 R. Williams and M. C. Galan, Eur. J. Org. Chem. 2017, 2017, 6247-6264.

8 (a) A. Düffels, L. G. Green, R. Lenz, S. V. Ley, S. P. Vincent and C.-H. Wong, Bioorg. Med. Chem. 2000, 8, 2519-2525. (b) L. Krasnova and C.-H. Wong, Annu. Rev. Biochem. 2016, 85, 599-630. (c) Z. Wang, Z. S. Chinoy, S. G. Ambre, W. Peng, R. McBride, R. P. de Vries, J. Glushka, J. C. Paulson and G.-J. Boons, Science, 2013, 341, 379-383. (d) L. Li, Y. Liu, C. Ma, J. Qu, A. D. Calderon, B. Wu, N. Wei, X. Wang, Y. Guo, Z. Xiao, J. Song, G. Sugiarto, Y. Li, H. Yu, X. Chen and P. G. Wang, Chem. Sci., 2015, 6, 5652-5661. (e) W. Li, A. Xiao, Y. Li, H. Yu and X. Chen, Carbohydr. Res. 2017, 451, 51-58.

9 (a) R. S. Lane, F. M. Haller, A. A. E. Chavaroche, A. Almond, and P. L. DeAngelis, Glycobiology, 2017, 27, 1062-1074. (b) D. Ruhela, S. Kivimäe and F. C. Szoka, Bioconjug. Chem. 2014, 25, 718-723. (c) M. P. Christie, P. Simerska, F. E.-C. Jen, M. P. Jennings and I. Toth, ChemPlusChem 2013, 78, 793-796.

10 G. T. Noble, F. L. Craven, M. D. Segarra-Maset, J. E. Reyes Martínez, R. Šardzík, S. L. Flitsch and S. J. Webb, Org. Biomol. Chem., 2014, 12, 9272-9278.

11 G. T. Noble, F. L. Craven, J. Voglmeir, R. Šardzík, S. L. Flitsch and S. J. Webb, J. Am. Chem. Soc. 2012, 134, 13010-13017.

12 S. J. Webb, K. Greenaway, M. Bayati and L. Trembleau, Org. Biomol. Chem. 2006, 4, 2399-2407.

13 R. Šardzík, A. P. Green, N. Laurent, P. Both, C. Fontana, J. Voglmeir, M. J. Weissenborn, R. Haddoub, P. Grassi, S. M. Haslam, G. Widmalm and S. L. Flitsch, J. Am. Chem. Soc. 2012, 134, 4521-4524.

14 T. M. Allen and A. Chonn, FEBS Lett. 1987, 223, 42-46.

15 R. J. Mart, K. P. Liem and S. J. Webb, Pharm. Res. 2009, 26, 1701-1710.

16 DPPC bilayers $\left(22^{\circ} \mathrm{C}\right.$, solid ordered phase) gave poorer batch-to-batch reproducibility than DMPC/chol. See the ESI.

17 A suspension of objects ca. 200-400 nm in diameter is formed at a $0.2 \mathrm{mM}$ concentration of 1 . See the ESI.

18 (a) C. Müller, G. Despras and T. K. Lindhorst, Chem. Soc. Rev. 2016, 45, 3275-3302. (b) L. L. Kiessling, J. E. Gestwicki and L. E. Strong, Angew. Chem., Int. Ed., 2006, 45, 2348-2368. (c) G. T. Noble, K. P. Liem, S. L. Flitsch and S. J. Webb, Org. Biomol Chem. 2009, 7, 5245-5254. (d) J. J. Lundquist and E. J. Toone, Chem. Rev., 2002, 102, 555-578.

19 C.-H. Lai, C.-Y. Lin, H.-T. Wu, H.-S. Chan, Y.-J. Chuang, C.-T. Chen and C.-C. Lin, Adv. Funct. Mater. 2010, 20, 3948-3958. 